\title{
PŘÍSPĚVEK K DĚJINÁM NĚKDEJŠÍ KNIHOVNY IGNÁCE KARLA HRABĚTE ZE ŠTERNBERKA († 1700). POKUS O REKONSTRUKCI SIGNATUROVÉHO ODDĚLENÍ B NA ZÁKLADĚ NOVĚ NALEZENÉHO KATALOGU*
}

\author{
Milada Svobodová (Praha)
}

\begin{abstract}
A Contribution to the History of the Former Library of Count Ignác Karel of Šternberk († 1700). An Attempt to Reconstruct the Shelf-Mark Section B on the Basis of a Newly Discovered Catalogue
\end{abstract}

\begin{abstract}
One of the most extensive and interesting aristocratic libraries in early Baroque Bohemia was built by Count Ignác Karel of Šternberk (Ignaz Karl von Sternberg) in his family seat at Zelená Hora Castle near Nepomuk in the last third of the 17th century. A large part of the defunct Zelená Hora library later somehow found its way to the National Library of the Czech Republic in Prague, where it now forms the largest extant collection of aristocratic libraries. This study deals with a recently discovered volume from the fragmentarily preserved series of library catalogues of the count's library. The 1684 catalogue covers the shelf mark B 'Ex Classe Scripturistarum', which contained an impressive collection of literature necessary for reading and studying the Bible. The vast majority of the books date from the 17th century and were published abroad, mostly in Paris, Lyon and Antwerp. The study presents an edition of the catalogue and attempts to identify extant copies. Out of the total of 149 shelf marks, it has been possible to find 18 books, including three binder's volumes, which means 22 books printed abroad in 1605-1684. It is worth mentioning the presence of Jansenist and anti-Jansenist works in the count's library.
\end{abstract}

Keywords: library history - aristocratic libraries - Bible reading and study - 17th century - Ignác Karel of Šternberk

K nejbohatším a nejzajímavějším šlechtickým knihovnám na území raně barokních Čech náležela nepochybně knihovna hraběte Ignáce Karla ze Šternberka, vybudovaná v rodovém sídle na zámku Zelená Hora u Nepomuku. Tato knihovna měla zvláštní osud; nestala se sice základem šternberské rodové knihovny, protože zanikla již mezi lety 1724 a 1726, ale během následujících dvou století velká část jejích knih různými cestami doputovala do fondu Národní knihovny ČR v Praze, kde dnes představuje největší dochovaný celek šlechtické knihovny.

Majitel knihovny pocházel z konopišt'ské větve rodu Šternberků, ${ }^{1}$ jeho rodiči byli dvorský maršálek a nejvyšší zemský sudí František Karel Matyáš ze Šternberka (16121648) a na svou dobu velmi vzdělaná Lidmila Kateřina Benigna rozená Kavková z Říčan (1614-1672). Dospělosti se dožili jejich synové Václav Vojtěch, Jan Norbert a Ignác Karel, kteří byli roku 1661 za zásluhy svých předků, především otce zastřeleného při švédském obléhání Prahy, restituováni do stavu řŕšských hrabat. Dostalo se jim univerzitního vzdělání, jež završili kavalírskými cestami. Roku 1661 se mladí Šternberkové vydali na cestu po Evropě, kterou zahájili ročním studijním pobytem v Lovani, dále cestovali po Španělském Nizozemí, Holandsku, Anglii a Francii. Nejmladší Ignác Karel poté zůstal v Paříži, odkud se vrátil do Čech, zatímco jeho bratři podnikli ještě cestu do Itálie. V letech 1664-1665 pak Ignác Karel absolvoval další cestu do Francie, kde pobýval především v Lyonu a Besançonu. ${ }^{2}$

Po návratu z Francie převzal hrabě Ignác Karel (16441700) svůj dědický podíl, zahrnující Horažd’ovice, Sedlice a Zalužany, tato panství ale již v roce 1676 odprodal bratru Václavu Vojtěchovi a žil pak zřejmě v sídle na Zelené Hoře. Svou úřední kariéru započal v roce 1669 a spojil ji s pražským apelačním soudem, kde působil nejprve jako rada, poté od roku 1691 jako viceprezident a konečně v roce 1696 převzal po bratrovi úřad prezidenta. ${ }^{3}$ Oženil se dvakrát, s Polyxenou Lidmilou Žd’árskou ze Žd’áru († 1691) a Marií Barborou z Hodic, obě manželství ale zůstala bezdětná. Hrabě zemřel na mrtvici dne 7 . března 1700 , v testamentu pak pamatoval i na svou knihovnu.

Knihovnu Ignáce Karla ze Šternberka ${ }^{4}$ zdědili rovným dílem jeho bratr Václav Vojtěch a jediný syn zesnulého bratra Jana Norberta. Ještě téhož roku však synovec Jan

\footnotetext{
* Tento př́spěvek byl vypracován v rámci institucionálního výzkumu Národní knihovny ČR, oblast 1: Výzkum dějin knižní kultury.

${ }^{1}$ K rodu Šternberků alespoň PALACKÝ - STERNBERG 2001, SEJK 2002-2003, JUŘ́́K 2013.

2 KULÍKOVÁ 2001.

WOITSCHOVÁ 2010, s. 44, č. 18, s. 46, č. 4, s. 76, č. 173.

${ }^{4}$ K dějinám knihovny TOBOLKA - HORÁK 1959, s. 108-112, MAŠEK 1991, s. 530-532, KULÍKOVÁ 2006, PALIČKOVÁ 2019, s. 137-139. Viz též heslo ze Šternberka, Ignác Karel dostupné na https://provenio.net/records/8d0c171c-6063-4833-a85b-998e16231243 [cit. 30.6 .2021 ].
} 
Josef (1671-1700) tragicky zahynul, když na zpáteční cestě z Říma utonul s manželkou a starší dcerou v rozbouřené řece Inn. Dědičkou panství Bechyně a Smiřice se tak stala dcera Marie Terezie (1699-1761), která se roku 1715 provdala za hraběte Jana Leopolda $z$ Paaru. Zděděnou polovinu knihovny hrabě Jan Josef odkázal Karlově univerzitě, tento odkaz se ale tehdy pro nezájem univerzity nerealizoval. Celá knihovna hraběte Ignáce Karla tak zůstala v majetku jeho bratra, pravděpodobně na zámku Zelená Hora.

Václav Vojtěch ze Šternberka (1641-1708) dosáhl vynikající kariéry, kterou započal roku 1672 jako dvorský maršálek. V roce 1690 byl jmenován prezidentem apelačního soudu a tento úřad zastával do roku 1696. Poté byl v letech 1696-1704 nejvyšším zemským sudím a svou kariéru zakončil v úřadu nejvyššího hofmistra. ${ }^{5}$ Jako první člen rodu obdržel Řád zlatého rouna. Vlastnil rozsáhlá panství v jihozápadních Čechách a na Litoměřicku. Zdědil Zelenou Horu, Vršovice a Zadní Ovenec (dnešní pražská Trója), dále získal od matky Libochovice a Budyni nad Ohř́, které ale v roce 1676 prodal, a od bratra koupil již zmíněné Horažd’ovice, Sedlice a Zalužany. Hrabě byl velkým mecenášem a stavebníkem, který zveleboval svá panství. Když roku 1665 převzal panství Zelená Hora, přestavěl pravděpodobně v letech 1670-1688 tamní hrad na barokní zámek. V letech 16791685 pak nechal postavit na panství Zadní Ovenec jako své letní sídlo zámek v Tróji a v letech 1698-1707 vybudoval na Hradčanech monumentální Šternberský palác. Stejně jako Ignác Karel však nezanechal žádné potomky. S manželkou Klárou Bernardinou z Maltzanu († 1719) měl sice tři syny, dospělosti se ale dožila pouze dcera Marie Barbora, provdaná za hraběte Aloise Tomáše z Harrachu, která zemřela již roku 1694. Hrabě tedy přežil své děti, bratry i synovce, za svého dědice proto určil vzdáleného bratrance Františka Leopolda. Do tehdy vytvořeného fideikomisu včlenil Šternberský palác na Hradčanech a panství Zelená Hora a Zadní Ovenec.

Hrabě Václav Vojtěch vybudoval vlastní knihovnu, která byla posléze umístěna ve Šternberském paláci na Hradčanech a stala se součástí fideikomisu, tedy skutečným základem budoucí rodové knihovny konopištské větve Šternberků. Dochované knihy mívají majitelovo heraldické supralibros, osmicípá šternberská hvězda s hraběcí korunkou a řádem Zlatého rouna s iniciálami W A C D S, a exlibris „Ex Bibliotheca Ill[ustrissi]mi D[omini] Wenceslai Adalbert Comitis a Sternberg “. Podle pozi̊stalostního inventáře z roku 1708 se mělo $\mathrm{v}$ palácové knihovně nacházet celkem 1521 knih, označených jako „Libri ad Bibliothecam Domus Sternbergicae spectantes "; tato knižní sbírka obsahovala 285 francouzských, 165 italských, 51 španělských, 633 latinských, 347 německých a 40 českých knih. ${ }^{6}$

Bratrovu knihovnu, uloženou snad stále na zámku v Zelené Hoře, ovšem Václav Vojtěch do fideikomisu nezahrnul; již před několika lety se ji rozhodl svěřit pražskému konventu irských františkánů (hybernů) u sv. Ambrože na Novém Městě pražském, který Šternberkové dlouhodobě podporovali. Roku 1701 proto $\mathrm{v}$ klášteře započala stavba nové knihovní budovy, již hrabě financoval. Zde měla být umístěna celá knihovna Ignáce Karla, aby sloužila veřejnosti (zu freien Nutzen des lieben Vatterlandes). Na nezbytné výlohy, nákup knih a platy dvou knihovníků určil hrabě v závěti celkem 300 zlatých ročně, $\mathrm{z}$ toho 150 zlatých z majetku praneteře Marie Terezie, který spravoval jako poručník. Velkorysý odkaz se však podařilo realizovat teprve po 16 letech, a to ve značně pozměněné podobě.

Rozhodující roli v dalším osudu knihovny hraběte Ignáce Karla sehrál dědic šternberského fideikomisu hrabě František Leopold (1680-1745), který v roce 1724 nalezl kompromis přijatelný pro všechny zúčastněné strany. Musel přitom zohlednit skutečnost, že se Karlova univerzita po letech přihlásila o své dědictví po hraběti Janu Josefovi. Vzhledem k zadluženosti šternberského majetku nebylo také možné vyplácet hybernům stanovenou roční rentu, proti níž vehementně protestovala hraběnka Marie Terezie z Paaru. Navíc hyberni mezitím začali budovu knihovny používat k jiným účelům. Dohoda uzavřená mezi hrabětem a klášterem hybernů 12. června 1724 stanovila, že polovina knihovny právoplatně náleží univerzitě. Hyberni mohli převzít druhou polovinu knih, a to bez podmínky umístit ji v novém knihovním křídle a zpř́stupnit veřejnosti, roční platby uložené Šternberkům a hraběnce Paarové byly zrušeny.

Po tomto narovnání se zřejmě knihovna Ignáce Karla rozdělila do tř́ celkủ, které měly různé osudy. Pravděpodobně ještě téhož roku provedli zástupci Karlovy univerzity výběr knih pro potřebu své právnické a lékařské fakulty, a označené knihy byly posléze předány do Karlovy koleje. Nová karolinská knihovna, jejímž základem se tak stala přibližně polovina knihovny Ignáce Karla ze Šternberka, byla již od května roku 1726 zdarma př́stupna veřejnosti. ${ }^{7}$ Roku 1777 vznikla sloučením novokarolinské knihovny, někdejší klementinské jezuitské knihovny a majorátní knihovny hrabat Kinských veřejná Univerzitní knihovna se sídlem v Klementinu; knihy hraběte Ignáce Karla byly proto z Karolina přestěhovány do Klementina a dnes jsou součástí fondu Národní knihovny ČR.

Druhou část hraběcí knihovny převzali v roce 1724 hyberni a včlenili ji do klášterní knihovny. ${ }^{8}$ Část knih byla zřejmě ještě téhož roku opatřena rukopisným exlibris „,Bibliothecae PP. Hibernorum ad S. Ambrosium anno 1724" nebo „Bibliothecae PP. Hibernorum ad S. Ambrosium Pragae $a b$ anno 1724". V roce 1752 klášterní knihovník Patrik Hackett založil dodnes dochovaný katalog 9 a do knih byly zapsány exlibris a signatura, např́klad ,Bibliothecae PP. Hibernorum ad S. Ambrosium Pragae. Sub lit. G. 4 ${ }^{\circ} .208^{\prime \prime}$. Klášterní knihovna, obsahující podle Hackettova katalogu

\footnotetext{
5 WOITSCHOVÁ 2010, s. 44, č. 17.

${ }^{6}$ KUBEŠ 2005, s. 251, pozn. 914. Ke knihovně viz též KULÍKOVÁ 2006, heslo ze Šternberka, Václav Vojtěch dostupné na https://provenio.net/ records/d163fa70-f8d8-4fec-aaf4-11c6550a4050 [cit. 30. 6. 2021].

TOBOLKA - HORÁK 1959, s. 147-148, pozn. 55.

${ }^{8}$ O klášterní knihovně PAŘEZ - KUCHAŘOVÁ 2001, s. 109-123, PALIČKOVÁ 2019, s. 133-135. Viz též heslo Klášter hybernů dostupné na https://provenio.net/records/fb50a9fb-8001-414b-98ef-5522b0fae9ed [cit. 30. 6. 2021].

9 Praha, NK ČR, sign. IX J 2.
} 
okolo 10 tisíc svazků, zanikla v roce 1786, kdy došlo $\mathrm{v}$ rámci josefinských reforem ke zrušení konventu. Podle platných nařízení byla tehdy hybernská knihovna sepsána a soupis obdržely pražská Univerzitní knihovna a dvorská studijní komise, jež měla přednostní právo výběru knih pro Dvorskou knihovnu ve Vídni. Klášterní knihovna byla převezena do Univerzitní knihovny v Klementinu, kde však knihovník Rafael Ungar (1744-1807) vytřídil duplikáty a knihy považované za bezcenné, ty byly rozprodány nebo skončily jako makulatura. Větší celek vytříděných knih získal přes židovského antikváře profesor astronomie a rektor Karlovy univerzity, ředitel hvězdárny v Klementinu Antonín Strnad (1746-1799); velká část Strnadovy knihovny se dnes nachází v knihovně premonstrátů na Strahově. ${ }^{10}$ Zbytek knih byl zcela rozptýlen a jednotliviny se dostaly do Knihovny Národního muzea, Muzea hl. města Prahy či do řady zámeckých knihoven. ${ }^{11}$

Třetí nejmenší celek tvořily zřejmě knihy, o něž Karlova univerzita ani klášter hybernů nestály, př́ípadně si je hrabě Václav Vojtěch či jeho dědic chtěli ponechat. Tyto knihy byly pravděpodobně zařazeny do knihovny ve Šternberském paláci, k čemuž muselo dojít nejpozději roku 1726, kdy bylo panství Zelená Hora prodáno Martinicům. Dosud nezmapovanou cestou se později hradčanská palácová knihovna (nebo její část) dostala do Šternberského paláce na Malostranském náměstí. Po smrti Františka Josefa ze Šternberka a Manderscheidu, který zemřel bez mužských potomků v roce 1830 , prodaly dědičky malostranskou palácovou knihovnu na úhradu dluhů. Třetinu knih, přibližně 4000 svazků, tehdy získal hrabě František Josef z Klebelsbergu (1774-1857). ${ }^{12}$ Zbývající dvě třetiny, přibližně osm tisíc svazků včetně sbírky rukopisů, koupil kníže August Longin z Lobkowicz (1797-1842). ${ }^{13}$ Tato část šternberské knihovny byla včleněna do fideikomisní knihovny v Lobkowiczkém paláci ve Vlašské ulici na Malé Straně. ${ }^{14}$ V roce 1928 prodali Lobkowiczové československému státu malostranský palác i s knihovnou, která byla předána do dnešní Národní knihovny ČR. V takzvané pražské lobkowiczké knihovně se tak nacházejí i knihy z majetku bratř́ Václava Vojtěcha a Ignáce Karla ze Šternberka.

Původní velikost knihovny Ignáce Karla ze Šternberka lze odhadnout jen na základě dochovaných knih, protože nám chybí prameny v podobě knihovních katalogů či pozůstalostních inventářù. První signaturový soupis knih dochovaných v Univerzitní knihovně publikoval Zdeněk Tobolka, který odhadl, že knihovna Ignáce Karla mohla mít přes dva a půl tisíce svazků, ${ }^{15}$ postupující katalogizace fondu starých tisků i rukopisů však stále přináší nové nálezy. ${ }^{16}$ Obsahově šlo o velmi zajímavou knižní sbírku, v níž byla zastoupena díla z oblasti teologie, historie, práva a prrírodních věd, militaria, publicistická literatura a beletrie, přičemž zřejmě převažovaly tisky 17 . století.

Počátky knihovny Ignáce Karla spadají nepochybně již do první poloviny 60 . let. První knihy potřebné ke studiu mu nejspíš darovali rodiče a starší bratři, například ve frankfurtském vydání Komenského díla Janua aurea quinque linguarum reserata z roku 1644 zůstalo přeškrtnuté exlibris Václava Vojtěcha. ${ }^{17} \mathrm{Na}$ svých kavalírských cestách si Václav Vojtěch a Ignác Karel vedli cestovní deníky, z nichž vyplývá, že navštívili řadu slavných knihoven a prohlédli si tiskárny v Antverpách a Leidenu. Pochopitelně také nakupovali knihy a mapy, např́klad v Amsterodamu, bohužel konkrétní tituly deníky neuvádějí. Bylo však již nalezeno 10 knih, které Ignác Karel koupil v srpnu a září roku 1664 v Lyonu a do nichž vepsal francouzsky své exlibris. ${ }^{18}$ Další knihy s podobným exlibris pak zakoupil $\mathrm{v}$ březnu roku 1665 v Paříži. ${ }^{19}$ Knihy pochopitelně kupoval i po návratu do Čech, větší nákupy můžeme doložit např́iklad v letech 1688 a 1689 v Kladsku. ${ }^{20}$ Svou knihovnu tak zřejmě rozšiřoval až do konce života, nejmladší tisky pocházejí z roku 1699.

Knihy z majetku hraběte Ignáce Karla poznáme často již podle vazby, kdy na obou deskách bývá vyzlaceno či černě vytlačeno majitelovo heraldické supralibros. Korunovaný štít se šternberskou osmihrotou hvězdou umístěný ve vavrrínových větvích doprovází opis IGNATIVS CAROLVS S. R. I. COMES DE STERNBERG. Toto supralibros bylo doplňováno i na původní, například nakladatelské vazby. ${ }^{21}$ Většina knih pak mívá na titulním listu latinské rukopisné exlibris, nejčastěji ve tvaru „Ex Bibliotheca Ill[ustrissi] mi ac Excell[entissi]mi D[omini] D[omini] Ignatij Caroli S[acri] R[omani] I[mperii] Comitis de Sternberg " nebo „Ex Bibliotheca Ill[ustrissi]mi D[omini] D[omini] Ignatij Caroli S[acri] R[omani] I[mperii] Com[itis] a Sternberg “, zapisované různýma rukama $\mathrm{v}$ různých variantách zkratek.

Zelenohorská knihovna byla zřejmě již v 80. letech 17. století uspořádána a zkatalogizována, což dokládají vepsané poznámky i signatury a jediný dosud známý katalog. Dochované exempláře mívají na předním přídeští poznámku o zařazení knihy do příslušného vědního oboru, například „Ex Classe Medicorum “, a občas také signaturu vytvořenou

\footnotetext{
${ }^{10}$ SEYDL 1939, KOUKLOVÁ 1989 (zde soupisy nalezených knih). Viz též heslo Strnad, Antonín dostupné na https://provenio.net/records/846c0a5274e6-4095-bc80-f0006f51c659 [cit. 30. 6. 2021].

${ }^{11}$ MAŠEK 1991, s. 532 uvádí zámecké knihovny Újezd Svatého Kř́že, Lipník nad Bečvou, Častolovice, Český Šternberk, Lysice, Křivoklát, Křimice a Mimoň.

${ }^{12}$ Srv. heslo z Klebelsbergu, František Josef dostupné na http://provenio.net/authorities/30888 [cit. 30. 6. 2021].

${ }^{13}$ Viz BEUTEL VON LATTENBERG 1853, s. 372-373.

${ }^{14}$ K pražské lobkowiczké knihovně alespoň LIFKA 1934, VOLF 1937, KAŠPAROVÁ 1991, KAŠPAROVÁ 2006.

${ }^{15}$ TOBOLKA - HORÁK 1959, s. 110-112 uvádí 2297 signatur.

${ }^{16}$ KULÍKOVÁ 2006 nalezla v NK ČR při průzkumu signaturových oddělení 9 a 19 celkem 190 nových signatur. PALIČKOVÁ 2019 uvádí 1400 svazků šternberské provenience. STT - Databáze prvotisků, starých tisků a map 1450-1800 NK ČR podchycuje aktuálně (30. 6. 2021) Ignáce Karla ze Šternberka jako majitele u 1280 záznamů, zčásti ovšem jde i o signatury nezachycené v Tobolkově seznamu.

${ }^{17}$ Praha, NK ČR, sign. 45 F 7.

${ }^{18}$ KULÍKOVÁ 2006, s. 209.

${ }^{19}$ Praha, NK ČR, sign. 21 J 134/1-3, 22 J 104.

${ }^{20}$ Praha, NK ČR, sign. 6 G 104, 22 G 295, 22 H 73, 22 H 319, 25 G 197, 35 G 211.

${ }^{21}$ Praha, NK ČR, sign. 12 A 34, 13 A 33.
} 
z velkého písmene, římské číslice a arabské číslice; tyto signatury byly ovšem později v pražské Univerzitní knihovně často přelepovány novými signaturovými štítky. ${ }^{22}$ Hraběcí knihovna byla rozdělena do tematických skupin, které zřejmě tvořily signaturová oddělení označená velkými písmeny. Těchto oddělení bylo prozatím identifikováno 21 (Ex Classe Historicorum, Historico-Politicorum, Historicorum et Politicorum, Politicorum, Humanistarum, Humanistarum et Aeconomicorum, Philologicorum, Oratorum, Poetarum, Philosophorum, Scripturistarum, Sanctorum Patrum, Theologorum Moralium, Ascetarum, Concionatorum, Conciliorum, Iuristarum, Canonistarum, Medicorum, Mathematicorum, Chymicorum) ${ }^{23} \mathrm{~S}$ růstem knihovny zřejmě narůstal i počet tematických oddělení, takže se někdy stalo, že byla kniha přeřazena do nového oddělení. Osignované knihy byly zapisovány do katalogů vytvořených pro jednotlivá signaturová oddělení. Dosud jsme však znali pouze katalog signaturového oddělení D vytvořeného pro knihy „,Ex Classe Mathematicorum “. Ten byl založen v 80. letech, 15. října neuvedeného roku, obsahuje lokační i jmenný katalog a podchycuje 218 signatur obsahujících díla nejenom z oboru matematiky, ale i astronomie, geografie, vojenské techniky a okultních věd. ${ }^{24} \mathrm{U}$ zbývajících signaturových oddělení neznáme jejich rozsah a často ani nejsme schopni určit, jaká písmena jim náležela. Na základě dochovaných signatur se ale např́íklad můžeme domnívat, že knihy , Ex Classe Historicorum “ tvořily signaturové oddělení $\mathrm{H}^{25}$ a svazky „Ex Classe Canonistarum “ stály na signatuře $\mathrm{K} .{ }^{26}$

Předpokládanou existenci celé řady katalogů jednotlivých signaturových oddělení v hraběcí knihovně potvrzuje i náš nález. Mezi rukopisy pražské lobkowiczké knihovny se totiž nachází další svazek této katalogové řady. ${ }^{27}$ Katalog byl založen 15. ř́jna 1684 pro signaturu B, tedy pro knihy „Ex Classe Scripturistarum“. Malý svazek, sestávající ze 45 listů o rozměrech $18,5 \times 12,5 \mathrm{~cm}$, nese původní koženou zlacenou vazbu. Na obou deskách vidíme majitelovo zlacené heraldické supralibros, nad nímž je vyzlacen trríŕádkový nápis SS: PP: ET SCRIPTVR: / SVB LITERA / B. Kniha se zapíná na dvě dírkové hranové spony. Na začátku čteme obšírný titul ,CATALOGVS DUPLEX SS. PP. ET SCRIPTVRISTARUM In Bibliotheca Illustrissimi D. D. IGNATII CAROLI S. R. I. Comitis a Sternberg etc. etc. sub Litera B contentorum Quorum prior eo Ordine, quo ibidem collocati sunt. Libros enumerati Posterior vero Authorum cognomina in Ordinem Alphabeti digesta recensent. Impositus est Anno 1684 Mense Octobri Die 15 “. Opět jde o dvojitý, tedy spojený lokační a jmenný katalog, psaný týmž knihovníkem jako katalog signatury D. Lokační katalog podchycuje celkem 149 signatur (B. I. 1-25, B. II. 1-19, B. III. 1-17, B. IV. 1-17, B. V. 1-30, B. VI. 1-30, B. VII.
1-11), prričemž u vícesvazkových děl měly jednotlivé svazky samostatnou signaturu. Následuje jmenný katalog týchž knih. Oba katalogy uvádějí signaturu, jméno autora a latinizovaný název díla, rozepisují konvoluty, ale nezaznamenávají místo ani rok vydání knihy.

Předkládaná studie přináší edici lokačního katalogu signatury B. Pokusili jsme se také o identifikaci dochovaných exemplářu, nakolik je ovšem vzhledem ke kvalitě katalogových záznamů možná. Z celkového počtu 149 zapsaných signatur (svazků) se podařilo nalézt 18 exemplářŭ, v tom tř̌ konvoluty. $\mathrm{K}$ tomu musíme připočítat další tisk s poznámkou „Ex Classe Scripturistarum“, který nebyl do katalogu zapsán. Všechny dochované knihy pocházejí z klášterní knihovny hybernů. Až na jednu výjimku také zůstaly v Praze, kde jsou uloženy v Národní knihovně ČR (16), Knihovně Národního muzea (1) a Knihovně Královské kanonie premonstrátů na Strahově (1). Další knihu dnes vlastní Diözesanbibliothek v dolnorakouském Sankt Pöltenu; pochází z odkazu tamního biskupa Josefa Fesslera (18131872). Celkem jde o 23 tisků z let 1605-1684 vydaných v Paříži (8), Lyonu (3), Antverpách (3), Monsu (1), Římě (1), Mnichově (1), Würzburgu (1), Kolíně nad Rýnem (1), Rintelnu (2), Jeně (1) a Salcburku (1).

Signaturové oddělení B obsahovalo bible, biblické konkordance, slovníky, encyklopedie a chronologie, exegetické spisy církevních Otců a středověkých autorů, novějši komentáře $\mathrm{k}$ biblickým knihám, různé biblické výtahy a historie. Bible stály v hraběcí knihovně na celkem 24 signaturách, řadu exempláŕů však nelze identifikovat. Pod titulem „Biblia Sacra in Versiculos distincta“ se zřejmě skrývá některé vydání oficiálního překladu Vulgáty, který za pontifikátu Klementa VIII. prripravil kardinál Roberto Bellarmino. S jistotou víme, že hrabě vlastnil osmidílnou latinskou bibli, kterou vytiskl Antoine Vitré v letech 16511652 v Pařiží; dochoval se totiž čtvrtý díl. Nepochybně měl také francouzské př̀klady bible. Tisk Le Nouveau Testament En François, vydaný roku 1696 u André Pralarda v Paříži, však není v katalogu uveden, byl totiž zařazen do oddělení „Ex Classe Historicorum “. ${ }^{28}$ Bylo by jistě zajímavé vědět, proč si obstaral polemický spis De La Lecture De L'Ecriture Sainte En Langue Vulgaire z roku 1679, v němž kanovník katedrály v Rouenu Charles Mallet (1608-1680) ostře napadl francouzský překlad Nového zákona vytvořený jansenisty z kláštera v Port Royal, i zda se posléze seznámil také s odpovědí jansenisty Antoina Arnaulda (1612-1694).

Hrabě vlastnil německý katolický překlad Nového zákona z pera Lutherova odpůrce Hieronyma Emsera (14781527) v kolínském vydání z roku 1684 a měl i jakousi německou bibli. V prípadě českého vydání Nového zákona by snad mohlo jít o druhý díl Svatováclavské bible z roku 1677; v knihovně byla též nějaká česká vydání Evangelií

\footnotetext{
${ }^{22}$ Praha, NK ČR, sign. 5 K 4 (Ex Classe Poetarum), 24 L 3 (Ex Classe Ascetarum), 21 G 159 (Ex Classe Scripturistarum).

${ }^{23}$ Osmnáct tematických skupin uvádí již KULÍKOVÁ 2006, s. 207.

${ }^{24}$ Praha, Knihovna Královské kanonie premonstrátů na Strahově, sign. DH V 27. Katalog popsal RYBA 1970, s. 156, č. 2011, v samostatné studii se jím bude zabývat kolegyně Jana Vackářová.

${ }^{25}$ Praha, NK ČR, sign. 22 L 52 (H. XI. 88), 22 L 87 (H. X. 204), 22 L 169 (H. XI. 235).

${ }^{26}$ Praha, NK ČR, sign. 24 J 77 (K. IX. 105), 24 L 79 (K. XI. 8), 25 J 55 (K. IX. 156).

${ }^{27}$ Praha, NK ČR, sign. XXIII F 109.

${ }^{28}$ Praha, NK ČR, sign. 26 K 62.
} 
a Epištol. Identifikovat nedokážeme pět svazků zřejmě vícedílné latinské bible ani exemplář označený jako ,, Biblia cum iconibus “. Víme také o dvou obrazových biblích, přičemž „Icones Biblicae utriusque Testamenti“ můžeme snad ztotožnit s tiskem Icones Biblicae Veteris et Novi Testamenti, který vydal roku 1679 v Ausgburgu tamní rytec Melchior Küssel (1626-1683). Při studiu bible hrabě využíval blíže neurčené Concordantiae Bibliorum. Nahlížet mohl i do některého z italských vydání proslulého biblického slovníku Vocabularium Ecclesiasticum, jehož autorem je savonský augustinián-eremita Giovanni Bernardo Forte († 1503/1504). K dispozici měl také dílo Chronologia Veteris Testamenti, které jezuita Heinrich Philippi (1575-1636) vydal roku 1637 v Kolíně nad Rýnem.

Knihovna obsahovala řadu novějších edic a překladů děl východních i západních církevních Otců. Pravděpodobně tu byla edice Sanctorum Bibliotheca Patrum Primitivae Ecclesiae vydaná roku 1680 v Lyonu. Dochoval se exemplář pařížského tisku Bibliothecae Graecorum Patrum Auctuarium Novissimum $\mathrm{z}$ roku 1672, tuto edici pořídil francouzský dominikán François Combefis (1605-1679). Proniknout do myšlenkového světa církevních Otců a dalších spisovatelů pomáhala čtenářům také různá florilegia. Součástí knihovny hraběte Ignáce Karla byla Adagia Ex Sanctorum Patrum Ecclesiasticorumque Scriptorum Monumentis Prompta, která vydal veronský theatin Luigi Novarini (1594-1650), a našli bychom zde i některé pařížské vydání sbírky Flosculi Sanctorum Patrum od Jeana de La Russalière.

Odkaz prvního latinsky píšícího křest’anského apologety Tertulliana (c. 160 - post 220) zprostředkovala čtenářum edice pařížského kapucína George d'Amiens († 1661). Kartuzián Theodor Petreius (1567-1640) vydal roku 1603 v Paříži spis Confessio Tertullianiana et Cyprianiana. Stěžejní dílo sv. Methodia z Olympu († c. 311) Convivium decem virginum přeložil z řečtiny vatikánský knihovník Leone Allacci (1586-1669), vzácný ŕímský tisk z roku 1656 se dostal do diecézní knihovny v Sankt Pöltenu. V knihovně bylo souhrnné dílo svatého poustevníka Efréma Syrského (306-373). Možná se tu vyskytovala i basilejská inkunábule z roku 1490 či 1491 zahrnující spis Jana Zlatoústého (c. 347-407) De compunctione cordis spolu s PseudoAugustinovým dílem De contritione cordis.

$\mathrm{V}$ hraběcí knihovně bychom našli abecedně uspořádané výbory klíčových slov a úryvků ze spisů svatých Ambrože (c. 340-397) a Augustina (354-430), jež sestavil italský augustinián Bartholomaeus de Urbino († 1350). Milleloquium sancti Ambrosii vyšlo tiskem roku 1556 v Lyonu, konkordanci k dílu sv. Augustina měl hrabě v edici Jeana Colliera, tedy v některém pařížském vydání z let 1645, 1649 nebo 1672. Svatý Augustin byl zastoupen i svými Confessiones, komentáŕi k žalmům a antologií Epitome Omnium Operum Divi Aurelii Augustini, kterou pořídil bývalý dominikán a reformovaný farář Johannes Piscatorius († 1565). Od svatého Jeronýma (c. 347-420) mohl hrabě číst v neznámém vydání jeho Epistolae. Nedochovaný kolínský tisk z roku 1678 nebo 1679 obsahoval kazatelské dílo dvou církevních Otců 5. století, ravennského biskupa sv. Petra Chrysologa a sv. Maxima, biskupa $\mathrm{v}$ Turíně. Dochoval se konvolut dvou pařížských tisků z let 1612 a 1605, edice homilií sv. Valeriána z Cimiez († c. 460) a díla lyonského biskupa sv. Agobarda (779-840). Součástí knihovny byla i dvousvazková opera omnia teologa první poloviny 6. století Pseudo-Dionysia Areopagity; snad šlo o jedno z pařížských vydání z roku 1644.

Zelenohorská knihovna obsahovala řadu děl středověkých teologů. Stály tu sebrané spisy sv. Bernarda z Clairvaux (c. 1090-1153) a zřejmě i dílo švýcarského cisterciáka Josepha Meglingera (1634-1695) Nova Melliflui Ecclesiae Doctoris S. Patris Bernardi Effigies ex Epitome Vitae ac selectis Epistolis concinnata, vydané v Badenu roku 1670. Hrabě mohl studovat exegetické dílo sv. Tomáše Akvinského (1225-1274); tř́dílná edice Davida Lenfanta (1603-1688) Biblia Sive Collectio Et Explicatio omnium locorum Sacrae Scripturae vyšla v Paříži v letech 1657-1659. Výrazněji byl zastoupen františkánský teolog sv. Bonaventura z Bagnoregia (c. 1221-1274). Hrabě vlastnil šestisvazkové souhrnné vydání Bonaventurových spisů, pravděpodobně šlo o lyonské vydání z roku 1668. Dokonce ve dvou exempláŕích měl pak rejstř́ky Tabula Seu Index Generalis In Opera Omnia S. Bonaventurae, které sestavil kapucín Bartolomeo Barbieri da Castelvetro (1615-1697); dochoval se lyonský tisk z roku 1681. Obstaral si také některý z německých překladů asketicko-mystického traktátu Stimulus divini amoris, připisovaného též ovšem mylně sv. Bonaventurovi. V neznámém vydání byly v knihovně oblíbené Flores Bibliorum, jejichž autorem byl snad irský klerik studující na Sorbonně Thomas Hibernicus (c. 1265 c. 1329). V průběhu 16. a 17. století opakovaně vycházely komentáře ke Knize žalmů, které sepsal doctor incognitus, boloňský karmelitán Michele Aiguani (c. 1320-1400). Náhradou za jinou vrácenou knihu se do oddělení B dostaly sebrané spisy nového světce, benátského biskupa a prvního patriarchy Lorenza Giustinianiho (1381-1456). A byl zde i spis o predestinaci, jehož autorem je byzantský teolog, patriarcha Konstantinopole Gennadios II. (c. 1405 - c. 1473), dílo vyšlo zásluhou českého jezuity Karla Libertina (16381683) roku 1681 ve Vratislavi.

Skutečně reprezentativní byla sbírka biblických komentářů sepsaných autory 16. a především 17. století, mezi nimiž převažují jezuité. Knihovna obsahovala 10svazkovou řadu biblických komentářů nizozemského jezuity Cornelia a Lapide (1567-1637), vydaných Jacobem van Meurs v Antverpách; dosud byly nalezeny tři svazky z let 1657 , 1659 a 1662. Italský jezuita Giovanni Paolo Oliva (16001681) byl zastoupen spisem In Selecta Scripturae Loca, Ethicae Commentationes v prvním lyonském vydání z let 1677-1679. Knihovna měla i některé z antverpských vydání komentár̆ů ke Starému a Novému zákonu z pera tamního jezuity Jakoba Tirina (1530-1636), biblické komentáře profesora kolínské univerzity Leonarda Maria (1588-1652), vydané roku 1621 v Kolíně nad Rýnem, nebo několik výkladů z pera italského dominikána Angela Paciuchelliho († 1660).

$\mathrm{V}$ hraběcí knihovně bychom ale našli i komentáře k Pentateuchu, které sepsal známý oponent jezuitů a zakladatel jansenismu, ypernský biskup Cornelis Jansen (15851638). Komentáře ke knihám Genesis a Exodus vydal španělský teolog, biskup v Tlaxcale Manuel Fernández de Santa Cruz y Sahagún (1637-1699) v letech 1681 a 1683 v Lyonu. 
Komentář ke Knize Jozue z pera jezuity Heinricha Marcellia (1593-1664), vydaný roku 1661 ve Würzburgu, nechal majitel svázat do konvolutu se třemi saskými právnickými tisky. Tři svazky komentářủ ke Knize soudců od španělského jezuity Manuela de Nájera (1604-1680) vyšly v Lyonu v letech 1651-1664. Ke Knize žalmů byly k dispozici ještě výklady jezuitů Jeana de Lorin (1559-1634) a Georga Hesera (1609-1676), u Heserova díla si hrabě pravděpodobně obstaral obě ingolstadtská vydání z let 1654 a 1678. Komentár k Písni písní sepsal mad'arský paulin Gergely Bánffy známý jako Gregorius Coelius (1472-1545), převor kláštera sv. Štěpána v Římě. Autorem dalšího výkladu Expositio Moralis Et Mystica In Canticum Canticorum je španělský jezuita Luis de la Puente (1554-1624); hrabě mohl vlastnit pařížské nebo kolínské vydání z let 1622-1623. Své komentáře k První a Druhé knize Makabejské vydal jezuita Jean Érard Foullon (1609-1668) v Liège roku 1660, 1664 a 1665. Pozoruhodný je výskyt spisu označeného jako „, Kabala et Commentarij in Vetus Testamentum “, pravděpodobně totiž jde o první svazek zásadního díla ke studiu kabaly Kabbala Denudata od německého básníka a hebraisty Christiana Knorra von Rosenroth (1638-1689), který vyšel v Sulzbachu v letech 1677-1678 a křest'anským učencům poprvé poskytl možnost seznámit se v latinském překladu se spisy židovských mystiků.

Méně početné byly komentáře k Novému zákonu. Hrabě si obstaral osm svazků komentářù, které sepsal druh Ignáce z Loyoly, španělský jezuita Alfonso Salmerón (15151585). Měl také lyonská či antverpská vydání komentářů k Evangeliím a Apokalypse, které sepsal portugalský karmelitán João da Sylveira (1592-1687), a komentáře k Jakubově epištole z pera španělského jezuity Ignacia de Zuleta (16281685). Dochoval se exempláŕ lyonského tisku z roku 1684 s výkladem Apokalypsy, jehož autorem je francouzský kněz a oratorián Daniel Hervé (c. 1621-1694). Titul „,Molitoris Apocalypsis " nedokážeme identifikovat.

$\mathrm{Z}$ různých biblických výtahů stojí za zmínku tři dochované tisky. Pro německé čtenáře připravil Georg Raw (15841660) Biblische Historien Aus Dem Alten unnd Newen Testament, které vyšly roku 1671 v Mnichově. Francouzský jansenista z kláštera Port Royal Nicolas Fontaine (16251709) publikoval v roce 1670 dílo L'Histoire Du Vieux Et Du Nouveau Testament; hrabě vlastnil pařížské vydání z roku 1680. Do katalogu nebyl zapsán salcburský tisk z roku 1682 Consilia Sapientiae Seu Epitome Axiomatum Salomonis, ačkoli nese poznámku ,Ex Classe Scripturistarum “;29 překlad anonymního francouzského spisu, jehož autorem byl snad jezuita Michel Boultauld (1607-1688), pořídil učený benediktin, knihovník kláštera v Kremsmünsteru Simon Rettenpacher (1634-1706). Především pro potřebu kazatelů vydal roku 1676 v Pasově premonstrát Michael Stainmayr († 1701) spis Verbum Abbreviatum, Seu Epitome totius Sacrae Bibliae.
Některé spisy byly věnovány jednotlivým biblickým postavám. Dílo Ioseph Rachelis filius illustratus vydal portugalský jezuita Luis Alvarez (1615-1709) v roce 1675 v Lyonu. Životopisy významných žen Starého a Nového zákona sepsal v italštině Tommaso Garzoni (1549-1589), Le Vite Delle Donne Illustri Della Scrittura Sacra četl zřejmě Ignác Karel v některém ze tř́ benátských vydání z let 1586-1588. O neposkvrněném početí Panny Marie pojednal španělský jezuita Juan Eusebio Nieremberg (1595-1658) v díle Opera Parthenica, které vyšlo roku 1659 v Lyonu; od téhož autora byly v knihovně také Homiliae Catenatae a Erotemata Theopolitica. V roce 1670 vydal u Gasparda Migeota v Monsu již zmíněný francouzský jansenista Antoine Arnauld (1612-1694) dílo Histoire Et Concorde Des Quatre Evangelistes, v němž představil na základě Evangelií Ježíšův život. Přeškrtané exlibris z roku 1670 svědčí o tom, že ještě před Ignácem Karlem vlastnil knihu hrabě František Eusebius z Pöttingu (1626-1678). ${ }^{30}$

$\mathrm{V}$ hraběcí knihovně se nacházela i díla $\mathrm{z}$ oblasti biblické eschatologie. Posmrtně vyšly v Bologni roku 1658 Disputationes De Fine Mundi, které napsal Alfonso Pandolfi († 1648), biskup v Comacchio. Postavou Antikrista se zaobírají dvě knihy. V př́padě dvousvazkového spisu De Antichristo, jehož autorem je španělský dominikán Tomaso Malvenda (c. 1566 - 1628), však šlo zřejmě o zápůjčku; kniha byla později vrácena blíže neurčeným dominikánům, snad šlo o pražský konvent u sv. Jiljí. V majetku hraběte Ignáce Karla tak zůstalo jen známé dílo Leben Antichristi z pera kapucína Dionysia von Luxemburg (1652-1703).

Náš průzkum nově nalezeného katalogu ukázal, že v zelenohorské knihovně tvořilo signaturové oddělení B ucelenou a vskutku reprezentativní sbírku literatury potřebné k četbě a studiu bible. Naprostá většina knih pochází ze 17. století a byla vydána v cizině, výrazně zastoupeny byly zřejmě pařížské, lyonské a antverpské tisky. Tato kolekce posléze nepochybně významně obohatila klášterní knihovnu hybernů u sv. Ambrože, odkud pocházejí všechny dosud identifikované exempláře. Zajímavý je výskyt jansenistických i protijansenistických tisků i fakt, že majitelem jednoho z nich byl původně jiný proslulý bibliofil, hrabě František Eusebius z Pöttingu. Do budoucna můžeme s postupující katalogizací a digitalizací historických fondů očekávat další nálezy nejenom knih, ale snad i katalogů zaniklé knihovny Ignáce Karla ze Šternberka.

Příloha. Edice lokačního katalogu signaturového oddělení B knihovny Ignáce Karla ze Šternberka. Praha, NK ČR, sign. XXIII F 209, ff. 4r-11v. ${ }^{31}$

\section{SCRIPTURA ET SCRIPTURISTAE SS. PP.}

B. I. 1. Lorini S. J. Commentationum in Psalmos Tom. I.

B. I. 2. Ejusdem Tom. II.

B. I. 3. Ejusdem Tom. III. ${ }^{32}$

\footnotetext{
${ }^{29}$ Praha, NK ČR, sign. 12 L 76.

${ }^{30}$ O Pöttingově knihovně KAŠPAROVÁ 2013, KAŠPAROVÁ 2014.

${ }^{31}$ Katalogové záznamy byly důsledně transliterovány, záznamy doplněné dalšíma rukama jsou odlišeny kurzívou. U dochovaných exemplářů byly opisy titulních listů po kontrole převzaty z STT - Databáze prvotisků, starých tisků a map 1450-1800.

${ }^{32}$ Lorin, Jean de, Commentarii In Librum Psalmorum: Tribus Tomis Comprehensi, Köln 1619, Mainz 1678.
} 
B. I. 4. Marij Operum omnium pars I. ${ }^{\mathrm{a}}$ et II. ${ }^{\mathrm{a} 33}$

B. I. 5. Incogniti Commentationum in Psalmos. Tom. I. et II. $^{34}$

B. I. 6. Alvarez S. J. Rachelis filius illustratus. ${ }^{35}$

B. I. 7. Sylveirae Operum in Textum Evangelicum Tom. I.

B. I. 8. Ejusdem Tom. II.

B. I. 9. Ejusdem Tom. III.

B. I. 10. Ejusdem Tomi IV ${ }^{\text {ti }}$ pars I. ${ }^{a}$ et II. ${ }^{a}$

B. I. 11. Ejusdem Tom. V.

B. I. 12. Ejusdem Tom. VI. ${ }^{36}$

B. I. 13. Ejusdem Commentarij in Apocalypsim Tom. VII. Pars I. ${ }^{\mathrm{a}}$

B. I. 14. Ejusdem Tom. VIII. pars II. ${ }^{37}$

B. I. 15. Ejusdem Opuscula Tom. IX. ${ }^{38}$

B. I. 16. Fulonij Commentarij in libr[um] I. ${ }^{\text {um }}$ Machabaeorum.

B. I. 17. Ejusdem in II. ${ }^{\text {um }}$ Machabaeorum. ${ }^{39}$

B. I. 18. Naxerae S. J. Commentarij in Judices Tom. I.

B. I. 19. Ejusdem Tom. II.

B. I. 20. Ejusdem Tom. III. ${ }^{40}$

B. I. 21. Biblia cum Iconibus.

B. I. 22. Barberij. Index Universalis In Opera S. Bonavent[urae]. ${ }^{41}$

= Praha, Knihovna Královské kanonie premonstrátů na Strahově, sign. BG III 46

Bonaventura z Bagnoregia, svatý, Bartolomeo da Castelvetro A R. P. BARTHOLOMAEI DE BARBERIIS A CASTROVETRO PROVINCIAE CAPUCCININORUM Lombardiae Definitoris, \& S. Theologiae Lectoris, TABULA SEV INDEX GENERALIS IN OPERA OMNIA S. BONAVENTURAE : IN QUO ALPHABETICO ORDINE COMPENDIOSE proponuntur omnia verba, sententiae, \& Conclusiones quae continentur in ejusdem Seraphici Doctoris scriptis \& Operibus :
EA SERIE DISPOSITUS, Ut omnibus editionibus hucusque Impressis usui esse possit.

LUGDUNI : Apud ANISSONIOS, \& JOAN. POSUEL, 1681.

Exlibris kláštera hybernů z roku 1724.

B. I. 23. Emmanuelis a S. Cruz. Antilogiae S. Scripturae. ${ }^{42}$

B. I. 24. Nierenbergij. Opera Parthenica ${ }^{43}$

B. I. 25. Barberij. Index u[nive]rs[a]lis in opera $S$. Bonavent [urae] ${ }^{44}$

B. II. 1. Malvendae de Anti-Christo. Tom. I.

B. II. 2. Ejusdem. Tom. II. ${ }^{45}$

restituti Dominicanis. D. Laurentij Justiniani opera. ${ }^{46}$ Nierembergij Homiliae Erotemata. ${ }^{47}$

B. II. 3. Olivae Commentationum in Genesim Tom. I. ${ }^{48}$

B. II. 4. Ejusdem Commentationum in Esdram. Tom. II. ${ }^{49}$

B. II. 5. Ejusdem Commentationum de Cyro Rege. Item Ejusdem Sermones Quadragesimae Tom. III. ${ }^{50}$

B. II. 6. Ejusdem Stromatum. Tom. I.

B. II. 7. Ejusdem eorundem. Tom. II.

B. II. 8. Ejusdem eorundem. Tom. III. ${ }^{51}$

B. II. 9. Zuletae S. J. Commentarij in Epistolam catholicam S. Jacobi Apostoli. ${ }^{52}$

B. II. 10. Cornelij a Lapide S. J. in Pentateuchum. ${ }^{53}$

B. II. 11. Ejusdem Commentarij in Josue. Judicum. Ruth. Regum. Paralipomenon. ${ }^{54}$

B. II. 12. Ejusdem in Ecclesiasten, Cantica, libr[um] Sapientiae.

= Praha, NK ČR, sign. 27 C 59

Lapide, Cornelius Cornelii a

COMMENTARII IN ECCLESIASTEN / AVCTORE R.P. CORNELIO CORNELII A LAPIDE, E SOCIETATE IESV,

${ }^{33}$ Snad Marius, Leonard, Commentariorum Leonardi Marii, SS. Theologiae Doct. Et In Universit. Colon. Profess. Ordinarii In Universam S. Scripturam, Köln 1621.

${ }^{34}$ Aiguani, Michele, Commentaria In Psalmos Davidicos, Prisci Cuiusdam Auctoris Incogniti, tom. 1-2, Lyon 1580, 1581, 1588, 1589, 1596, 1608, $1610,1652,1672,1673$, Venezia 1600,1601, 1603.

${ }_{35}^{35}$ Alvarez, Luis, Ioseph Rachelis Filius Illustratus, Lyon 1675.

${ }^{36}$ Sylveira, João da, Commentarii In Textum Evangelicum Sex Tomis Distincti, tom. 1-6, Lyon 1652, 1655, 1662, 1679, 1681, 1684, Antwerpen $1665,1676$.

${ }^{37}$ Sylveira, João da, Commentaria In Apocalypsim B. Joannis Apostoli, tom. 1-2, Lyon 1667-1669, 1681, Antwerpen 1671.

${ }^{38}$ Sylveira, João da, Opuscula Varia: Triplici Indice Illustrata, Lyon 1675.

${ }^{39}$ Foullon, Jean Érard, Commentarii Historici Et Morales Perpetui Ad Primum [Secundum] Machabaeorum Librum, Liège 1660, $1664,1665$.

${ }^{40}$ Nájera, Manuel de, In Iudices Commentarii Litterales, Moralesque, tom. 1-3, Lyon 1651, 1656, 1664.

${ }^{41}$ Srv. sign. B. I. 25.

${ }^{42}$ Fernández de Santa Cruz y Sahagún, Manuel, Conciliatio Genesis Et Exodi Locorum Qui Apparentem Continent Antinomiam, Simulque Expositio Moralis, Lyon 1681, 1683.

${ }^{43}$ Nieremberg, Juan Eusebio, Opera Parthenica De Super-Eximia Et Omni-Moda Puritate Matris Dei, Lyon 1659.

${ }^{44}$ Srv. sign. B. I. 22.

${ }^{45}$ Malvenda, Tomaso, De Antichristo, Roma 1604, Lyon 1647.

${ }^{46}$ Lorenzo, Giustiniani, svatý, Divi Laurentii Iustiniani Protopatriarchae Veneti, Opera omnia, Venezia 1606, Köln 1616, 1675.

${ }^{47}$ Nieremberg, Juan Eusebio, Homiliae Catenatae, Sive Collectaneae Ex Vetustis Patribus, Sacris Doctoribus, [et] eruditis Scriptoribus: Item eiusdem Auctoris Erotema Curiosae Lectionis Liber Singularis, Antwerpen 1651.

${ }^{48}$ Oliva, Giovanni Paolo, In Selecta Scripturae Loca Ethicae Commentationes. In Genesim: Cui Accessere Commentationes Item Ethicae In Canticum Canticorum. Tomus Primus, Lyon 1677.

${ }^{49}$ Oliva, Giovanni Paolo, In Selecta Scripturae Loca Ethicarum Commentationum Tomus Secundus, In Esdram, Lyon 1677.

${ }^{50}$ Oliva, Giovanni Paolo, In Selecta Scripturae Loca, Ethicae Commentationes. Ex Capite Primo Esdrae: Sive De Cyro Rege: Quibus Adjecta Prolegomena Ad Stromata, Seu Dissertationes Super Evangeliis Quadragesimae ad Academicos Christianos. Tomus Tertius, Lyon 1679.

${ }^{51}$ Oliva, Giovanni Paolo, Ethicarum Commentationum In Selecta Scripturae loca, Tomus Quartus [Quintus. Sextus]. Stromatum Ex Divinis Scripturis. Tomus Primus [Secundus. Tertius], Lyon 1677-1679.

${ }^{52}$ Zuleta, Ignacio de, Iacobus, Seu Commentaria Litteralia Et Moralia In Epistolam Catholicam S. Iacobi Apostoli, Lyon 1668, Antwerpen 1672.

${ }^{53}$ Lapide, Cornelius Cornelii a, Commentaria In Pentateuchum Mosis, Antwerpen 1615, 1616, 1618, 1623, 1630, 1648, 1659, 1671, 1672, 1681, Paris 1621, 1637.

${ }^{54}$ Lapide, Cornelius Cornelii a, Commentarius In Iosue, Iudicum, Ruth, IV. Libros Regum Et II. Paralipomenon, Antwerpen 1642, 1653, 1664, 1676. 
S. Scripturae olim Louanij, postea Romae Professore: INDICIBVS NECESARIIS ILLVSTRATI.

Antverpiae : Apud Iacobvm Mevrsivm, 1657.

Př́vazek 1:

COMMENTARII IN CANTICVM CANTICORVM / AVCTORE R.P. CORNELIO CORNELII A LAPIDE E SOCIETATE IESV, S. Scripturae olim Louanij, postea Romae Professore: INDICIBVS NECESARIIS ILLVSTRATI.

Antverpiae : Apud Iacobvm Mevrsivm, 1657.

Př́ivazek 2:

COMMENTARII IN LIBRVM SAPIENTIAE / AVCTORE R.P. CORNELIO CORNELII A LAPIDE E SOCIETATE IESV, S. Scripturae olim Louanij, postea Romae Professore: INDICIBVS NECESARIIS ILLVSTRATI.

Antverpiae : Apud Iacobvm Mevrsivm, 1657.

Heraldické supralibros Ignáce Karla ze Šternberka, na titulním listu ,Ex Bibliotheca Ill[ustrissi]mi D[omini] D[omini] Ignatij Caroli S[acri] R[omani] I[mperii] Comitis De Sternberg “. Na př. př́ideští „Ex Classe Scripturistarum “. Exlibris kláštera hybernů „,Bibliothecae PP. Hibernoru[m] ad S. Ambrosium Pragae".

B. II. 13. Ejusdem in Ecclesiasticum. ${ }^{55}$

B. II. 14. Ejusdem in Proverbia Salomonis.

= Praha, NK ČR, sign. 27 C 58

Lapide, Cornelius Cornelii a

COMMENTARIA IN SOLOMONIS PROVERBIA / Auctore R.P. CORNELIO CORNELII A LAPIDE e Societate IESV.

Antverpiae : Apvd Iacobvm Mevrsivm, 1659.

Heraldické supralibros Ignáce Karla ze Šternberka, na titulním listu ,Ex Bibliotheca Ill[ustrissi]mi D[omini] D[omini] Ignatij Caroli S[acri] R[omani] I[mperii] Comitis De Sternberg “. Na př. př́́deští „Ex Classe Scripturistarum “. Exlibris kláštera hybernů „Bibliothecae PP. Hibernorum ad S. Ambrosium Pragae".

B. II. 15. Ejusdem in Proph[etas] Majores. ${ }^{56}$

B. II. 16. Ejusdem in Proph[etas] Minores. ${ }^{57}$

B. II. 17. Ejusdem in Evangelia. ${ }^{58}$

B. II. 18. Ejusdem in acta Aposto[lorum]. Epist[olas]. Canon[icas]. Apocal[ypsim].
$=$ Praha, NK ČR, sign. 27 C 60

Lapide, Cornelius Cornelii a

COMMENTARIA IN ACTA APOSTOLORVM, EPISTOLAS CANONICAS, ET APOCALYPSIN / Auctore R.P. CORNELIO CORNELII A LAPIDE, e Societate IESV, olim in Louaniensi, post in Romano Collegio Sacrarum Litterarum Professore.

Antverpiae : Apud Iacobvm Mevrsivm, 1662.

Heraldické supralibros Ignáce Karla ze Šternberka, na titulním listu „,Ex Bibliotheca Ill[ustrissi]mi D[omini] D[omini] Ignatij Caroli S[acri] R[omani] I[mperii] Comitis de Sternberg “. Na př. prrídeští „Ex Classe Scripturistarum “. Exlibris kláštera hybernů „Bibliothecae PP. Hibernoru[m] ad S. Ambrosium Pragae. A. $255^{\prime \prime}$.

B. II. 19. Ejusdem in Epistol[as] S. Pauli. ${ }^{59}$

B. III. 1. Tirini S. J. Commentarij in utrumque Testamentum. ${ }^{60}$ B. III. 2. Heseri S. J. Commentarij in 155 psalmos. ${ }^{61}$

B. III. 3. Lud[ovici] de Ponte S. J. Comment[arii] in cant[ica] Canticorum. ${ }^{62}$

B. III. 4. Pandulphi de Fine Mundi. ${ }^{63}$

B. III. 5. Paciucheli Commentariorum in Jonam Tom. I.

B. III. 6. Ejusdem. Tom. II. ${ }^{64}$

B. III. 7. Ejusdem Commentarij in psalmos 86. Magnificat. Salutationem Angelicam et Salve Regina. ${ }^{65}$

B. III. 8. Ejusdem Commentarij in Epist[olam] S. Pauli ad Romanos. ${ }^{66}$

B. III. 9. Coelij Commentarij in Cantica Canticorum. ${ }^{67}$

B. III. 10. Salmeronis S. J. Com[m]entarij in Evangeli[cam historiam]. Tom. I. et II.

B. III. 11. Ejusdem eorundem Tom. III. et IV.

B. III. 12. Ejusdem. Tom. V. et VI.

B. III. 13. Ejusdem. Tom. VII. et VIII.

B. III. 14. Ejusdem. Tom. IX. et X.

B. III. 15. Ejusdem. Tom. XI. et XII.

B. III. 16. Ejusdem Commentarij in Episto[las] S. Pauli. Tom. XIII. et 14 .

B. III. 17. Ejusdem in Epist[olas] S. Pauli. Tom. XV. et $\mathrm{XVI}^{68}$

\footnotetext{
${ }^{55}$ Lapide, Cornelius Cornelii a, Commentaria In Ecclesiasticum, Antwerpen 1634, 1638, 1643, 1663, 1665, 1674.

${ }^{56}$ Lapide, Cornelius Cornelii a, Commentaria In Quatuor Prophetas Maiores, Antwerpen 1621, 1622, 1625, 1630, 1633, 1634, 1654, 1664, 1675,1676

${ }^{57}$ Lapide, Cornelius Cornelii a, Commentaria In Duodecim Prophetas Minores, Antwerpen 1625, 1628, 1640, 1646, 1660, 1661, 1673, Paris 1630, 1635 .

${ }_{58}^{58}$ Lapide, Cornelius Cornelii a, Commentarius In Quatuor Evangelia, Antwerpen 1639, 1660.

${ }^{59}$ Lapide, Cornelius Cornelii a, Commentaria In Omnes Divi Pauli Epistolas, Antwerpen 1614, 1617, 1621, 1627, 1635, 1654, 1656, 1661, 1665, $1670,1675,1679$

${ }^{60}$ Tirinus, Jacobus, In S. Scripturam Commentarius Duobus Tomis Comprehensus, Antwerpen 1632, 1645, 1656, 1668.

${ }^{61}$ Heser, Georg, Psalmi Davidis Regis Centum Et Quinquaginta : Iuxta sensum litteralem explanati, Ingolstadt, Georg Hänlin, 1654, 1678. Viz sign. B. VI. 5.

${ }^{62}$ Puente, Luis de la, Expositio Moralis Et Mystica In Canticum Canticorum : Continens Exhortationes, Sive Sermones, De Omnibus Christianae Religionis Mysteriis Atque Virtutibus ; In Duos Tomos Distributa, Paris 1622, Köln 1622-1623.

${ }^{63}$ Pandolfi, Alfonso, Disputationes De Fine Mundi : In Quibus Quaecunque a varijs Philosophorum Sectis in hoc argumento naturali lumine sunt constituta, refelluntur : Evangelica, Propheticaque doctrina unice recipitur, \& propugnatur, Bologna 1658.

${ }^{64}$ Paciuchelli, Angelo, Lectiones Morales In Prophetam Jonam, tom. 1-2, Antwerpen 1680, München 1672-1679.

${ }^{65}$ Paciuchelli, Angelo, Excitationes Dormitantis Animae Circa Psalmum Octogesimum Sextum. Canticum Magnificat, Salutationem Angelicam, \& Antiphonam Salve Regina, Venezia 1659, 1671, 1680, München 1677, 1682.

${ }^{6}$ Paciuchelli, Angelo, Expositio In Epistolam Beati Pauli Apostoli Ad Romanos: Ex Sanctis Patribus, Et Sacris Doctoribus Collecta, München 1677, 1682.

${ }^{67}$ Coelius, Gregorius, Commentaria In Cantica Canticorum Salomonis ... Opus Posthumum, Wien 1681.

${ }^{68}$ Salmerón, Alfonso, Commentarii In Evangelicam Historiam, Et in Acta Apostolorum, tom. 1-16, Madrid 1598-1601, Köln 1602-1604, $1612-1615$.
} 
B. IV. 1. Bibliotheca SS. PP. primitivae Ecclesiae. ${ }^{69}$

B. IV. 2. S. Bonaventurae Commentarij in vetus Testamentu[m]. Tom. I.

B. IV. 3. Ejusdem in novum Testamentum. Tomus II. Item Sermones de Tempore et Sanctis. Tom. III.

B. IV. 4. Ejusdem in Librum I. ${ }^{\text {um }}$ et II. ${ }^{\text {um }}$ Sententiarum. Tom. IV.

B. IV. 5. Ejusdem in Libr[um] III. ${ }^{\text {um }}$ et IV. ${ }^{\text {um }}$ Sententiarum.

Tom. V.

B. IV. 6. Ejusdem I. ${ }^{a}$ et II. ${ }^{\mathrm{a}}$ pars Opusculorum. Tom. VI.

B. IV. 7. Ejusdem III. ${ }^{\text {a }}$ et IV pars Opusculorum. Tom. VII. ${ }^{70}$

B. IV. 8. Callierij [!] Milleloquium S. Augustini. ${ }^{71}$

B. IV. 9. Vrbinatis Milleloquium S. Ambrosij. ${ }^{72}$

B. IV. 10. Biblia Sacra in Versiculos distincta.

B. IV. 11. S. Bernardi Opera omnia. ${ }^{73}$

B. IV. 12. Combefis Bibliotheca graecorum Patrum.

= Praha, NK ČR, sign. 28 E 7

Combefis, François

BIBLIOTHECAE GRAECORUM PATRUM AUCTARIUM NOVISSIMUM, IN QUO VARIA SCRIPTORUM ECCLESIASTICORUM, Antiquioris, medii \& vergentis aevi, Opuscula / FLAVII JOSEPHI. S. HIPOLYTI Episc. \& Mart. S. METHODII Episc. \& Mart. CLEMENTIS STROMATEI. SEVERIANI Gabal. Episc. PHOTII PATRIARCH. C. P. NICETAE PAPHLAGONIS. ALEXANDRI LYCOPOLIT. DIDYMI ALEXANDRINI. MANUELIS CALECAE, Ord. Praed. ET ALIORUM; QUORUM TRACTATUS proxima post Monitum lectorem pagina indicat. FR. FRANCISCUS COMBEFIS, Ordinis FF. Praedicatorum Provinciae sancti Ludovici strictioris observantiae, pleraque nova produxit: omnia recensuit, suaque vena Latio reddidit, ac continuis Notis illustravit.

ET PARISIIS : Venundat SEBASTIANUS MABRECRAMOISY, Regis Typographus, via

Jacobaea, sub Ciconiis; Excudit AEGIDIUS HOTOT, Bibliop. Aurelian, 1672.

Heraldické supralibros Ignáce Karla ze Šternberka, na titulním listu „Ex Bibliotheca Ill[ustrissi]mi D[omini]
D[omini] Ignatij Caroli S[acri] R[omani] I[mperii] Comitis de Sternberg“. Na př. přídeští „Ex Classe S[an]ctorum Patrum " a sign. ,C. II. 3“. Exlibris kláštera hybernů „Bibliothecae PP. Hibernoru[m] ad S. Ambrosium Pragae ab an[n]o 1724".

B. IV. 13. Novarini Adagia S.S. Patrum. ${ }^{74}$

B. IV. 14. Ambianatis Tertullianus illustratus. Tom. I.

B. IV. 15. Ejusdem Tom. II.

B. IV. 16. Ejusdem Tom. III. ${ }^{75}$

B. IV. 17. Novum Testamentum Bohemicè.

B. V. 1. Operum S. Dionysij Areop[agitae] Tom. I.

B. V. 2. Ejusdem Tom. II. ${ }^{76}$

B. V. 3. Opera S. Ephrem. ${ }^{77}$

B. V. 4. S. Augustini Commentarij in Psalmos. ${ }^{78}$

B. V. 5. Piscatorij Epitome Operum S. Augustini. ${ }^{79}$

B. V. 6. Biblia Sacra Germanica.

B. V. 7. Pexenfelderi S. J. Florus Biblicus. ${ }^{80}$

B. V. 8. Concordantiae Bibliorum.

B. V. 9. Icones Biblicae utriusque Testamenti. ${ }^{81}$

B. V. 10. Jansenij Pentatevchus. ${ }^{82}$

B. V. 11. Kabala et Commentarij in vetus Testamentum. ${ }^{83}$

B. V. 12. Marcelli S. J. in Josue et Praeceptum 6. et 7. um Decalogi. Item Strauchij amoenitates Juris Canonici.

= Praha, NK ČR, sign. 27 J 22

Marcellius, Henricus

COMMENTARIUS IN LIBRUM JOSUE. Quo declaratur Ingressus, Occupatio, Descriptio Terrae Sanctae ad Veteris ac Novi Testamenti interpretationem cognitu necessaria / à R. P. HENRICO MARCELLIO, Societatis JESU, SS. Theologiae D. [et] ejusdem olim in Rhemensi, Molshemensi, Moguntina, nunc in Bambergensi Academia SS. Canonum Professore. Accedit DISSERTATIO THEOLOGOPOLITICA. De optima Regiminis formâ, \& Virtutibus ad felicem gubernationem potissimè necessariis. Exercitati Academicae proposita, à Sacrorum Canonum Auditoribus. Herbipoli : Formis \& Impensis ChristophorI Kuchleri, 1661.

\footnotetext{
${ }^{69}$ Snad Sanctorum Bibliotheca Patrum Primitivae Ecclesiae, Sive Opera Authorum Veterum In Scripturam Sacram, Lyon 1680.

${ }^{70}$ Pravděpodobně Bonaventura, svatý, Opera Omnia, In Tomos septem distributa / Sixti V. Pont. Maximi Iussu Diligentissime Emendata, tom. 1-7 (6 vol.), Lyon 1668.

${ }^{71}$ Augustin, svatý, Bartholomaeus de Urbino, Collier, Jean, Milleloquium Veritatis / Olim A Fr. Bartholomaeo Ord. S. Augustini Urbinate Episcopo Digestum; Nunc vero plurimis eiusdem Sancti Sententiis locupletatum. Opera Ioann. Collierii Presbyteri Theologi, Paris 1645, 1649, 1672 .

${ }^{72}$ Ambrož, svatý, Bartholomaeus de Urbino, Divi Ambrosii Milleloquium Summam Totius Doctrinae Illius Ambrosii Sub Mille Titulis, Seu Generalibus Capitibus Ordine Alphabetico Digestis Complectens, Lyon 1556.

${ }^{73}$ Bernard z Clairvaux, svatý, Opera Omnia, Paris 1527, 1536, 1540, 1548, 1572, 1586, 1602, 1615, 1632, 1640, 1667, Lyon 1520, 1538, 1546, Antwerpen 1609, 1616, 1620, Köln 1641.

${ }^{74}$ Novarini, Luigi, Adagia Ex Sanctorum Patrum Ecclesiasticorumque Scriptorum Monumentis Prompta, Lyon 1635, 1637, 1638 , Verona 1651.

${ }^{75}$ Tertullianus, Ambianates, Georgius, Tertullianus Redivivus Scholiis Et Observationibus Illustratus, tom. 1-3, Paris 1646-1650.

${ }^{76}$ Pseudo-Dionysios Areopagita, Sancti Dionysii Areopagitae Operum Omnium Quae Extant, Et Commentariorum Quibus Illustrantur, tom. 1-2, Paris 1644 .

${ }^{77}$ Efrém Syrský, svatý, Sancti Ephraem Syri, Patris Et Scriptoris Ecclesiae Antiquissimi Et Dignissimi, Opera Omnia, Köln 1603, $1616,1675$.

${ }^{78}$ Augustin, svatý, Ennarationes, sive Commentarii in Psalmos mysticos, např. Paris 1542, 1543, Lyon 1571.

${ }^{79}$ Augustin, svatý, Piscatorius, Johannes, Epitome Omnium Operum Divi Aurelii Augustini, Augsburg 1537, Köln 1539, 1542, 1549, Venezia 1542, Paris 1555

${ }^{80}$ Pexenfelder, Michael, Florus Biblicus Sive Narrationes Ex Historia Sacra Testamenti Veteris Selectae Et Doctrina Morali Illustratae, Landshut 1672, Straubing 1672, München 1680.

${ }^{81}$ Snad Küssel, Melchior, Icones Biblicae Veteris et Novi Testamenti. Figuren Biblischer Historien Alten und Neuen Testaments, Augburg 1679, Köln 1679 [1680].

${ }^{82}$ Jansen, Cornelis, Pentateuchus Sive Commentarius In Quinque Libros Moysis, Leuven 1641, 1660, Paris 1649, 1661, 1677, Lyon 1677.

83 Pravděpodobně Knorr von Rosenroth, Christian, Kabbala Denudata Seu Doctrina Hebraeorum Transcendentalis Et Methaphysica Atque Theologica, Sulzbach 1677, Frankfurt am Main 1684.
} 
Př́ivazek 1:

Drösemar, Achatius Wilhelm

DISPUTATIO INAUGURALIS IURIDICA EXHIBENS PRAECEPTUM DECALOGI NON

MOECHABERIS : Ex JURE NATURALI ET POSITIVO Cum DIVINO Tum HUMANO deductum / Quam Deo Ter Optim. Max. Auxiliante EX DECRETO ET AUTORITATE Inclyti Ordinis JURISCONSULTORUM IN ILLUSTRI SCHAUMBURGICA PRAESIDENTE DN. BERNHARDO Schultzen JCto Celebratissimo, Consiliario \& Consistorii Hassiaci Adsesiore Gravissimo, Juridicae Facultatis DECANO Spectatissimo Patrono ac Promotore sancte colendo PRO LICENTIA Summos in utroque jure honores \& privilegia DOCTORALIA legitime \& ritu Majorem obtinendi Publico \& Placido Eruditorum examini subiicit ACHATIVS GVILIELMVS DRÖSEMARIVS GRONOVIENSIS. IN AUDITORIO JURIDICO diebus 9. \& 10. Maii Anno 1676. RINTHELII : Typis G. C. Wächters Acad. Typogr., [1676]. Př́vazek 2:

Bode, Heinrich von

NEGATIVUM DIVINAE MAJESTATIS Praeceptum; NON FURTUM FACIES; PUBLICA DISPUTATIONE IURIDICA, Ex jure Naturali \& Positivo utroque, cum Divino tum etiam humano deductum / PRAESIDE Viro Nobilissimo, Consultissimo atque Excellentissimo DN. BERNHARDO Schulzen, JCto Consiliario Hassiaco atque hujus Academiae Antecessore undiquaque celebratissimo: Dno Promotore ac Praeceptore suo Parentis instar observando Publico Doctorum Examini IN ACROATERIO JURIDICO, XVIII. CALEND. MART. Subjiciet HENRICUS BODINUS, Author \& Respondens.

RINTHELII : Imprimebat G. C. Wächters, Acad. Typogr., 1671.

Př́vazek 3:

Strauch, Johann

JOHANNIS STRAUCHI[I] Amoenitatum JURIS CANONICI Semestre : Quadruplici Indice Instructum.

JENAE : Operis atque impensis SAMUELIS ADOLPHI MÜLLERI, Bibliopolae \& Typographi, 1674.

Heraldické supralibros Ignáce Karla ze Šternberka, na titulním listu ,Ex Bibliotheca Ill[ustrissi]mi D[omini] D[omini] Ignatij Comitis de Sternberg “. Exlibris kláštera hybernů „Bibliothecae PP. Hibernorum ad S. Ambrosium Pragae an[n]o 1724 ".

B. V. 13. Philippi S. J. Examen Chronologiae veteris Testamenti. ${ }^{84}$

B. V. 14. S. Chrysologi Sermones in Dominicas et Festa. Item S. Maximini Episcopi. ${ }^{85}$
B. V. 15. Raw Historiae Biblicae utriusque Testamenti. = Praha, NK ČR, sign. 21 G 159

\section{Raw, Georg}

Biblische Historien : Aus Dem Alten unnd Newen Testament Ordenlich Von Zeit zu Zeit, Sambt kurzer Erklärung und Sittlichen Lehr-Stucken dem Teutschen und Christlichen Leser zu gutem gezogen / durch Georgivm Raw, Der Societät Jesu priestern.

München : Gedruckt und verlegt, durch Johann Jäcklin, 1671.

Heraldické supralibros Ignáce Karla ze Šternberka, na titulním listu ,Ex Bibliotheca Ill[ustrissi]mi D[omi]ni Ignatij Comitis de Sternberg“. Na př. př́ideští „Ex Classe Scripturistarum“. Exlibris kláštera hybernů „,Bibliothecae PP. Hibernorum ad S. Ambrosium Pragae an[n]o 1724“.

B. V. 16. Genadij de Praedestinatione, cum Commentario P. Libertini. ${ }^{86}$

B. V. 17. Ejusdem de eadem. ejectus

B. V. 18. Struvij de Incarnatione Verbi divini.

B. V. 19. Matth[aei] a Castro. Epitome Com[m]ent [ariorum] Jansenij.

= Praha, NK ČR, sign. 31 G 47

Jansenius, Cornelius, Du Château, Mathieu

D.N. CORNELII IANSENII EPISCOPI GANDAVENSIS, COMMENTARIORVM IN

SUAM CONCORDIAM, AC TOTAM HISTORIAM EVANGELICAM EPITOME : Additis

tribus indicibus quicquid toto opere tractatur exactissime demonstrantibus / Opera, [et]

industria F. MATTHAEI A CASTRO Insulensis, in Coenobio Falempinensi Canonici.

Lugduni : Apud Antonium Briasson, in vico Mercatorio, sub signo Solis, 1684.

Heraldické supralibros Ignáce Karla ze Šternberka. Exlibris kláštera hybernů „Bibliothecae PP. Hibernorum ad $S$. Ambrosium Pragae ab anno 1724".

B. V. 20. Molitoris Apocalypsis.

B. V. 21. Dionys [ii] à Lutzemburg. Historia Antichristi. ${ }^{87}$

B. V. 22. Historia Novi et Veteris Testam[enti].

B. V. 23. Eadem.

B. V. 24. Lefant S. Thomae Biblia. Tomus I.

B. V. 25. Ejusdem, ejusdem, eadem. Tomus II.

B. V. 26. Ejusdem, ejusdem, eadem. Tomus III.

= Praha, NK ČR, sign. 27 H 14/1-3

Tomáš Akvinský, svatý, Lenfant, David

SANCTI THOMAE AQVINATIS DOCTORIS ANGELICI, ORDINIS PRAEDICATORVMBIBLIASIVECOLLECTIO

\footnotetext{
${ }^{84}$ Philippi, Henricus, Chronologia Veteris Testamenti Accuratum Examen Augustissimae Invictissimae[que] Domui Austriacae Dicatum, Köln 1637.

${ }^{85}$ Petr Chrysolog, svatý, Maxim z Turína, svatý, D. Petri Chrysologi Archiepiscopi Ravennatis, Viri eruditissimi atque sanctissimi, Sermones In Evangelia De Dominicis Et Festis : Aliquot solemnioribus totius anni, insignes Cum Triplici Indice Evangeliorum, Et Epistolarum, Locorum S. Scripturae, Rerumque \& verborum, in lucem editi. Quibus accesserunt S. Maximi Episcopi Taurinensis Homiliae Hyemales \& Aestivales pariter insignes, Köln 1678, 1579 [recte 1679].

${ }^{86}$ Gennadios II., konstantinopolský patriarcha, Libertin, Karel, Gennadius De Praedestinatione Latinitate Donatus Et Commentariis Illustratus, Wrocław [1681].

${ }^{87}$ Dionysius von Luxemburg, Leben Antichristi Oder Außführliche gründliche und Historische Beschreibung Von den zukünfftigen Dingen der Welt, 1.-4. vydání Frankfurt am Main 1682-1695.
} 
ET EXPLICATIO omnium locorum Sacrae Scripturae, quae sparsim reperiuntur in omnibus S. Thomae Scholasticis operibus, Ordine Biblico. Tomus Primus, complectens quinque libros Moysi / Labore F. DAVIDIS L'ENFANT Parisini Doctoris, Theologi, Ordinis FF. Praedicatorum.

Parisiis : Apud Ioannem Henavlt, Bibliopolam Iuratum, via Iacobaea, sub signo Angeli Custodis, \& S. Raphaëlis, 1657. Na titulním listu exlibris Ignáce Karla ze Šternberka „Ex Bibliotheca Ill[ustrissi]mi D[omi]ni D[omi]ni Comitis Ignatij de Sternberg “. Na př. prŕ́deští „Ex Classe Scripturistarum “. Exlibris kláštera hybernů „,Bibliothecae PP. Hibernorum ad S. Ambrosium Pragae. Sub. Lit. A. $4^{\circ}$. $48^{\prime \prime}$.

SANCTI THOMAE AQVINATIS DOCTORIS ANGELICI, ORDINIS PRAEDICATORVMBIBLIASIVE COLLECTIO ET EXPLICATIO omnium locorum Sacrae Scripturae, quae sparsim reperiuntur in omnibus S. Thomae Scholasticis operibus, Ordine Biblico. Tomus Secundus, complectens Libros Iosue, Iudicum [et]c. vsque ad Psalmos inclusiue / Labore F. DAVIDIS L'ENFANT Parisini Doctoris, Theologi, Ordinis FF. Praedicatorum.

Parisiis : Apud Ioannem Henavlt, Bibliopolam Iuratum, via Iacobaea, sub signo Angeli. Custodis, \& S. Raphaëlis, 1659. Na titulním listu exlibris Ignáce Karla ze Šternberka „Ex Bibliotheca Ill[ustrissi]mi D[omi]ni D[omi]ni Comitis Ignatij de Sternberg “. Na př. př́́deští „, Ex Classe Scripturistaru [m] “. Exlibris kláštera hybernů „Bibliothecae PP. Hibernorum ad S. Ambros[ium] Pragae. Sub. Lit. A. 4․ $49^{\prime \prime}$.

SANCTI THOMAE AQVINATIS DOCTORIS ANGELICI, ORDINIS PRAEDICATORVM BIBLIA SIVE COLLECTIO ET EXPLICATIO omnium locorum Sacrae Scripturae, quae sparsim reperiuntur in omnibus S. Thomae Scholasticis operibus, Ordine Biblico. TOMVS TERTIVS, COMPLECTENS LIBROS Salomonis, \&c. vsque ad finem Veteris Testamenti / Labore F. DAVIDIS L'ENFANT Parisini, Doctoris Theologi, Ordinis FF. Praedicatorum.

Parisiis : Apud Ioannem Henavlt, Bibliopolam Iuratum, via Iacobaea, sub signo Angeli

Custodis, \& S. Raphaëlis, 1659.

Na titulním listu exlibris Ignáce Karla ze Šternberka „Ex Bibliotheca Ill[ustrissi]mi D[omi]ni D[omi]ni Comitis Ignatij de Sternberg “. Na př. př́́deští „, Ex Classe Scripturistaru [m] “. Exlibris kláštera hybernů „Bibliothecae PP. Hibernorum ad S. Ambrosium Pragae. Sub. Lit. A. 4․ 50".

B. V. 27. Garzoni Vitae Illustrium Faeminar[um] ex $S$. Scriptura. ${ }^{88}$

B. V. 28. Concordia 4. Evangelistaru[m].

= Praha, NK ČR, sign. 27 L 118

Arnauld, Antoine

HISTOIRE ET CONCORDE DES QUATRE EVANGELISTES, CONTENANT SELON L'ORDRE DES TEMPS la Vie \& Les Instructions de N. S. IESVS-CHRIST. A Mons : Chez Gaspard Migeot, en la ruë de Chaussée, aux trois Vertus, 1670.

$\mathrm{Na}$ titulním listu přeškrtané exlibris Františka Eusebia z Pöttingu „Francisci /// de Pötting 1670“ a exlibris Ignáce Karla ze Šternberka „Ex Bibliotheca Ill[ustrissi]mi D[omi] ni D[omi]ni Comitis Ignatij de Sternberg “. Na př. př́ídeští „Ex Classe Scripturistar[um]“. Exlibris kláštera hybernů „Bibliothecae PP. Hibernorum ad S. Ambrosium Pragae“.

B. V. 29. Hervei Explanatio Apocalipsis. = Praha, NK ČR, sign. 27 H 12

Hervé, Daniel

APOCALYPSIS BEATI JOANNIS APOSTOLI EXPLANATIO HISTORICA / Authore DANIELE HERVÉO Nannetensi, Oratorii Jesu Christi Domini nostri Presbytero. Lvgdvni : Sumptibus Petri Borde; Joannis; \& Petri Arnaud, 1684.

Heraldické supralibros Ignáce Karla ze Šternberka, na titulním listu „Ex Bibliotheca Ill[ustris] D[omini] D[omini] Ignatij Caroli S[acri] R[omani] I[mperii] Com[itis] â Sternberg “. Na př. př́ideští „Ex Classe Scripturistaru[m]“. Exlibris kláštera hybernů „Bibliothecae PP. Hibernorum Ord[inis] Minor[um] Strict[ioris] obs[ervanti]ae ad S. Ambrosium Pragae. Sub lit. A. $4^{\circ}$. 46".

B. V. 30. Embser novum Testamentum.

= Praha, NK ČR, sign. 26 K 19

Emser, Hieronymus

Das New Testament Durch den Hochgelehrten Herrn Hieronymum Embser, trewlich verteutscht, wie es unter deß Durchleuchtigsten, Hochgebohrnen, Hochlöblichen, Catholischen Fürsten, Weyland Hertzogen Georgen zu Sachsen, [et]c. Regiment erstlich außgangen ist : Jetzo auffs newe corrigirt, und von vielen groben Fehlern auffs fleissigst Castigirt und gebessert : Mit einem newen ewig-wehrenden Calender, und ordentlichem Register, der Sonn- und Feyrtäglichen Evangelien und Episteln, auch mit schönen Figuren gezieret.

Getruckt zu Cölln : Bey Simon Wolffgang, unter Helmschläger im gölden Haupt., 1684.

Heraldické supralibros Ignáce Karla ze Šternberka, na titulním listu ,Ex Biblioth[eca] Ill[ustrissi]mi D[omi]ni D[omi] ni Comitis Ignatij Caroli de Sternberg “. Na př. př́ideští „Ex Classe Scripturistarum“. Exlibris kláštera hybernů „Bibliothecae PP. Hibernorum ad S. Ambrosium Pragae ab an[n]o 1724".

B. VI. 1. Biblia Sacra.

B. VI. 2. Methodij Convivium decem Virginum.

= Sankt Pölten, Diözesanbibliothek, sign. K-J-VI-9 ${ }^{89}$

Metoděj z Olympu, svatý, Allacci, Leone

S. P. N. METHODII EPISCOPI ET MARTYRIS CONVIVIVM DECEM VIRGINVM LEO ALLATIVS, Hactenus non editum primus Graece vulgauit, Latine vertit, Notas \& Diatribam de METHODIORVM scriptis adiecit. ROMAE : Typis S. Congreg. De Propaganda Fide, 1656. Heraldické supralibros Ignáce Karla ze Šternberka, na titulním listu „Ex Bibliotheca Ill[ustrissi]mi Ignatij Comitis de Sternberg “. Exlibris kláštera hybernů „Bibliothecae PP. Hibernorum ad S. Ambrosium Pragae. Sub lit. H. 8. $214^{\circ}$.

B. VI. 3. S. Valeriani Homiliae et Opera Agobardi. = Praha, NK ČR, sign. 29 J 20

\footnotetext{
${ }^{88}$ Garzoni, Tommaso, Le Vite Delle Donne Illustri Della Scrittura Sacra, Venezia 1586, 1588.

${ }^{89}$ Popis exempláře dostupný na https://dasp.at/wp-content/uploads/2020/06/Kerens-Autorenkatalog.pdf [cit. 24. 6. 2021].
} 
Valerianus Cemenelensis, svatý

SANCTI VALERIANI EPISCOPI CEMELIENSIS HOMILIAE XX. : Item Epistola ad Monachos, de virtutibus [et] ordine doctrinae Apostolicae : Omnia nunc primum, praeter vnicam Homilian, post annos plus minus mille ducentos in lucem edita.

LVTETIAE PARISIORVM : EX OFFICINA NIVELLIANA : Sumptibus SEBASTIANI

CRAMOISY, via Iacobaea, sub Ciconiis, 1612.

Přivazek:

Agobardus, svatý

SANCTI AGOBARDI EPISCOPI ECCLESIAE LVGDVNENsis Opera : QVAE OCTINGENTOS ANNOS in tenebris delituerant : Nunc e Papirij Massoni Iurisconsulti Bibliotheca proferuntur : ACCESSERVNT BINAE EPISTOLAE LEIDRADI, non antea excusae : Operum seriem pagella decima tertia indicabit.

PARISIIS : Excudebat Dionysius Duvallius, sub Pegaso, In vico Bellovaco, 1605.

$\mathrm{Na}$ titulním listu ,Ex Bibliotheca Ill[ustrissi]mi D[omini] D[omini] Ignatij Caroli S[acri] R[omani] I[mperii] Comitis De Sternberg “. Na př. prí́deští „Ex Classe SS. Patrum “ [!]. Exlibris kláštera hybernů „Bibliothecae PP. Hibernoru[m] Ord[inis] Minorum ad S. Ambrosium Pragae. Sub lit. A. $8^{\circ}$. 51 ".

B. VI. 4. Petrei Confessio Tertulliani, et Cypriani. ${ }^{90}$

B. VI. 5. Heseri S. J. 155. Psalmi Davidis. ${ }^{91}$

B. VI. 6. Chrysostomi de Compunctione, et Augustini de

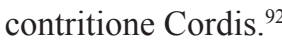

B. VI. 7. Steinmajeri Epitome Veteris et novi Testamenti. ${ }^{93}$

B. VI. 8. Confessiones S. Augustini.

B. VI. 9. Bibliorum Pentatevchus.

B. VI. 10. Bibliorum Liber Josue, Judicum, Ruth, Regum.

B. VI. 11. Bibliorum Libri Paralipomenon. Esdrae.

B. VI. 12. Bibliorum Psalmi, Proverbia, Ecclesiastes, cantica, Sapientia, Ecclesiasticus.

$=$ Praha, KNM, sign. 102 E $9^{94}$

Liber PSALMORVM. PROVERBIA. ECCLESIASTES. CANTIC. CANTICOR. SAPIENTIA. ECCLESIASTICVS. Tom. IV.

PARISIIS : Excudebat Antonius Vitre, 1651.
Neúplný exemplář, chybí titulní list. Heraldické supralibros Ignáce Karla ze Šternberka, exlibris „Ex Bibliotheca Ill[ustrissi]mi D[omini] D[omini] Ignatij Comitis de Sternberg“. Na př. př́́deští „Ex Classe Scripturistarum “. Exlibris kláštera hybernů ,,Bibliothecae PP. Hibernorum ad S. Ambrosium Pragae".

B. VI. 13. Prophetae Majores.

B. VI. 14. Prophetae Minores. Libri Machaboeorum. Esdrae.

B. VI. 15. Novum Testamentum.

B. VI. 16. Acta Apostolorum. Epistolae Canonicae omnes. ${ }^{95}$

B. VI. 17. Moreti S. J. Soliloquia in psalmos..$^{96}$

B. VI. 18. De lectione S. Scripturae Malet. ${ }^{97}$

B. VI. 19. Russalieri Flosculi SS. Patrum. Tom I. et II.

B. VI. 20. Ejusdem eorundem .Tom. III. et IV.

B. VI. 21. Ejusdem eorundem. Tom. V. ${ }^{98}$

B. VI. 22. Flores Bibliorum Hibernici. ${ }^{99}$

B. VI. 23. Evangelia Bohemica, et Epistolae.

B. VI. 24. Evangelia Latina, et graeca, et Epistolae.

B. VI. 25. Discursus de Initijs Mundi.

B. VI. 26. Royaumond. Historia Veteris et Novi Testamenti. = Praha, NK ČR, sign. 21 J 212

Fontaine, Nicolas

L'HISTOIRE DU VIEUX ET DU NOUVEAU TESTAMENT, Avec des Explications édifiantes, tirées des Saints Peres pour regler les moeurs dans toute sorte de conditions, Dédiée à Monseigneur le Dauphin / Par le Sieur de ROYAUMOND Prieur de Sombreval.

Suivant la Copie imprimée A Paris : Chez Pierre Le Petit, Imprimeur \& Libraire ordinaire du

Roy, ruë S. Jacques, à la Croix d'Or, 1680.

Heraldické supralibros Ignáce Karla ze Šternberka. Exlibris kláštera hybernů „Bibliothecae PP. Hibernorum ad S. Ambrosium Pragae. Sub lit. A. $8^{\circ}$. $48^{\prime \prime}$.

B. VI. 27. Meglinger. Epistolae S. Bernardi. ${ }^{100}$

B. VI. 28. Steinmayeri Epitome Bibliorum. ${ }^{101}$

B. VI. 29. Bernardi Vocabularium Ecclesiasticum. ${ }^{102}$

B. VI. 30. Icones Biblicae.

B. VII. 1. S. Hieronymi Epistolae.

B. VII. 2. Bibliorum Pentatevchus.

B. VII. 3. Liber Josue. Judicum. Ruth. Regum.

${ }^{90}$ Petreius, Theodor, Confessio Tertullianiana Et Cyprianiana In Quatuor Digesta Libros, Paris 1603.

${ }^{91}$ Heser, Georg, Psalmi Davidis Regis Centum Et Quinquaginta : Iuxta sensum litteralem explanati, Ingolstadt 1654, 1678. Viz sign. B. III. 2.

${ }^{92}$ Snad prvotisk. Jan Zlatoústý, svatý / Pseudo-Augustinus, De compunctione cordis / De contritione cordis. [Basel, Michael Furter, c. 1490].

${ }^{93}$ Stainmayr, Michael, Verbum Abbreviatum, Seu Epitome totius Sacrae Bibliae veteris \& novi Testamenti : Omnibus Verbi Divini Concionatoribus utilissimum, Passau 1676. Srv. sign. B. VI. 28.

${ }^{94}$ Popis exempláre dostupný na https://retris.nkp.cz/Catalog? catalogId=knmkct\&recordId=00120473 [cit. 30. 6. 2021].

${ }^{95}$ Biblia Sacra, Vulgatae Editionis / Sixti V. Pont. Max. authoritate recognita : Nunc vero Iussu Cleri Gallicani Denuo edita, tom. 1-8, Paris $1651-1652$.

${ }^{96}$ Moretus, Theodor, Soliloquia ad obtestationes Davidicas; et psalmorum allegoriae, Antwerpen 1656.

${ }^{97}$ Mallet, Charles, De La Lecture De L'Ecriture Sainte En Langue Vulgaire, Rouen 1679.

${ }_{98}$ La Russalière, Jean de, Flosculi Sanctorum Patrum, In Areolas Suas Distributi. Labore \& studio Ioannis De La Russaliere, Sacerdotis Pictaviensis, tom. 1-5, Paris $1667,1670$.

${ }_{99}$ Thomas of Ireland, Flores Bibliorum, Sive Loci Communes Omnium Fere Materiarum Ex Veteri Ac Novo Testamento Excerpti / Et alphabetico ordine digesti a F. Thoma Hibernico, Antwerpen 1555, 1557, 1567, 1572, Köln 1611.

${ }^{100}$ Pravděpodobně Bernard z Clairvaux, svatý, Meglinger, Joseph, Nova Melliflui Ecclesiae Doctoris S. Patris Bernardi Effigies ex Epitome Vitae ac selectis Epistolis concinnata, Baden 1670.

${ }^{101}$ Srv. sign. B. VI. 7.

${ }^{102}$ Forte, Giovanni Bernardo, Vocabularium Ecclesiasticum, Firenze 1508, Perugia 1518, Treviso 1649, Venezia 1607, 1616, 1619, 1623, 1626, $1637,1644,1653,1662,1671,1680,1686,1698$, Roma 1614, 1669, 1670. 
B. VII. 4. Esdrae, Tobiae, etc. usque ad Ecclesiasticum Libri.

B. VII. 5. Prophetae Majores, Minores, Libri Machabaeorum.

B. VII. 6. Novum Testamentum.

B. VII. 7. S. Bonaventurae Stimulus divini amoris germanicè. ${ }^{103}$

B. VII. 8. Novum Testamentum.

B. VII. 9. Evangelia Bohemica.

B. VII. 10. Sententiae ex novo Testamento.

B. VII. 11. Monachi Loci communes ex sacris, et profanis Authoribus. ${ }^{104}$

\section{Literatura:}

BEUTEL VON LATTENBERG 1853: BEUTEL VON LATTENBERG, Felix Valois. Die fürstl. Lobkowicz'sche Fideicommiss-Bibliothek zu Prag. Libussa 12, 1853, s. 369-375.

JUŘÍK 2013: JUŘÍK, Pavel. Šternberkové. Panský rod v Čechách a na Moravě. Praha: Knižní klub, 2013.

KAŠPAROVÁ 1991: KAŠPAROVÁ, Jaroslava. Pražská lobkovická knihovna jako součást fondu Státní knihovny ČSR. Documenta Pragensia IX/1, 1991, s. 245-256. KAŠPAROVÁ 2006: KAŠPAROVÁ, Jaroslava. Oddělení 65 - Pražská lobkowiczká knihovna. In: FALTYSOVÁ, Vlasta (ed.). Rukovět' tištěných knihovnich fondů Národní knihovny České republiky. Praha: Národní knihovna České republiky, 2006, s. 150-156.

KAŠPAROVÁ 2013: KAŠPAROVÁ, Jaroslava. Po stopách knižní sbírky Františka Eusebia hraběte z Pöttingu a Persingu (1626-1678). In: KRUŠINSKÝ, Rostislav - VINTROVÁ, Tereza (edd.). Bibliotheca Antiqua 2013. Sbornik z 22. konference, 30.-31. řijna 2013. Olomouc: Vědecká knihovna v Olomouci, 2013, s. 112-121.

KAŠPAROVÁ 2014: KAŠPAROVÁ, Jaroslava. Po stopách knižní sbírky Františka Eusebia hraběte z Pöttingu a Persingu (1626-1678). Část II. Knihy a dějiny 21, 2014, č. 1-2, s. 4-42.

KOUKLOVÁ 1989: KOUKLOVÁ, Michaela. Knihovna astronoma Antonína Strnada. Ondřejov: Středisko vědeckých informací Astronomického ústavu ČSAV, 1989.

KUBEŠ 2005: KUBEŠ, Jiří. Reprezentační funkce sídel vyšši šlechty z českých zemí (1500-1700). České Budějovice 2005. Disertační práce. Jihočeská univerzita v Českých Budějovicích. Historický ústav.

KULÍKOVÁ 2001: KULÍKOVÁ, Martina. Cesty bratři ze Šternberka a jejich cestovní deníky. Praha 2001. Diplomová práce. Univerzita Karlova v Praze. Filozofická fakulta.

KULÍKOVÁ 2006: KULÍKOVÁ, Martina. Šternberská knihovna. In: FALTYSOVÁ, Vlasta (ed.). Rukovět tištěných knihovních fondů Národni knihovny České republiky. Praha: Národní knihovna České republiky, 2006, s. 206-209.

LIFKA 1934: LIFKA, Bohumír. Zámecké a palácové knihovny v Čechách. Český bibliofil 6, 1934, s. 39-54.

MAŠEK 1991: MAŠEK, Petr. Příspěvky k dějinám zámeckých knihoven západních Čech (Chodová Planá, Lázeň,
Merklín, Poběžovice, Zelená Hora). Sbornik archivních praci 41, 1991, č. 2, s. 511-534.

PALACKÝ - STERNBERG 2001: PALACKÝ, František STERNBERG, Zdeněk. Dějiny rodu Sternbergů. Geschichte der Familie Sternberg. Moravský Beroun: Moravská expedice, 2001.

PALIČKOVÁ 2019: PALIČKOVÁ, Tereza. Bibliotheca nationalis v Národní knihovně ČR. In: KRUŠINSKÝ, Rostislav (ed.). Bibliotheca Antiqua 2019. Sbornik z 28. konference, 13.-14. listopadu 2019. Olomouc: Vědecká knihovna v Olomouci, 2019, s. 131-141.

PAŘEZ - KUCHAŘOVÁ 2001: PǍ̌EZ, Jan KUCHAŘOVÁ, Hedvika. Hyberni v Praze. Éireannaigh i BPrág. Dějiny františkánské koleje Neposkvrněného početí Panny Marie v Praze (1629-1786). Praha: Oswald, 2001.

RYBA 1970: RYBA, Bohumil. Soupis rukopisu Strahovské knihovny Památníku národního písemnictví v Praze. Díl IV. Praha: Památník národního písemnictví, 1970.

SEJK 2002-2003: SEJK, Roman. Urozenost, majetek a moc. (Šternberkové v 16. a 17. století). Středočeský sbornik historický 28-29, 2002-2003, s. 3-54.

SEYDL 1939: SEYDL, Otto. Knihovna astronoma Antonína Strnada, ředitele pražské hvězdárny (1746-1799). Praha: Pražská hvězdárna, 1939.

TOBOLKA - HORÁK 1959: TOBOLKA, Zdeněk HORÁK, František. Národní a universitní knihovna v Praze, její vznik a vývoj. I. Počátky knihovny až do r. 1777. Praha: Státní pedagogické nakladatelství, 1959.

VOLF 1937: VOLF, Josef. Knihovna lobkowiczkého fideikomisu v Praze. In: O starých českých sběratelích knih. Praha: Spolek českých bibliofilů, 1937, s. 19-24.

WOITSCHOVÁ 2010: WOITSCHOVÁ, Klára. Personální obsazení pražského apelačního soudu v letech 1548-1783: „,... což slušného a spravedlivého jest fedrovati ... “. Pelhřimov: Nová tiskárna Pelhřimov, 2010.

\section{Internetové zdroje:}

PROVENIO. Virtuální rekonstrukce knižních celků [online]. Dostupné z: https://www.provenio.net [cit. 24. 6. 2021]. STT - Databáze prvotisků, starých tiski̊ a map 1450-1800 [online]. Dostupné z: https://www.nkp.cz [cit. 24. 6. 2021]. VD 17. Das Verzeichnis der im deutschen Sprachraum erschienenen Drucke des 17. Jahrhunderts [online]. Dostupné z: http://www.vd17.de [cit. 24. 6. 2021].

WorldCat. Dostupné z: http://www.worldcat.org [cit. 24. 6. 2021].

Milada Svobodová
Národní knihovna České republiky
Klementinum 190
11000 Praha 1

\section{Milada Svobodová}

Klementinum 190

11000 Praha 1

\footnotetext{
${ }^{103}$ Existuje více rukopisných i tištěných německých překladů. Snad Stimulus divini amoris : d. ist, Stachel göttl. Liebe, [Köln] 1656.

${ }^{104}$ Snad Antonios Melissa: Sententiae Sive Loci Communes Ex Sacris \& profanis authoribus ab Antonio Monacho, cognomento Melissa collecti, Antwerpen 1555, 1560, Lyon 1555.
} 